Louisiana State University

LSU Digital Commons

\title{
Variability of the Reverse-Flow Concentration Technique of Measuring Plankton Respiration
}

\author{
R. Eugene Turner \\ euturne@Isu.edu
}

Follow this and additional works at: https://digitalcommons.Isu.edu/oceanography_coastal_pubs

\section{Recommended Citation}

Turner, R. (1978). Variability of the Reverse-Flow Concentration Technique of Measuring Plankton Respiration. Estuaries, 1 (1), 65-68. Retrieved from https://digitalcommons.Isu.edu/ oceanography_coastal_pubs/168 


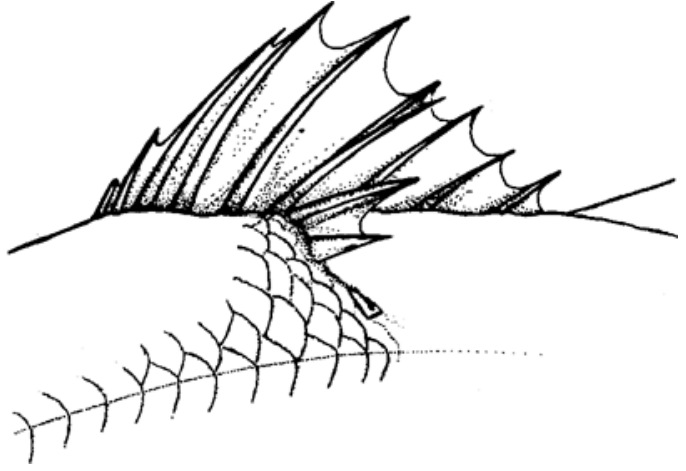

Fig. 1. Line drawing of specimen of white perch detailing the anomalous first dorsal fin spines.

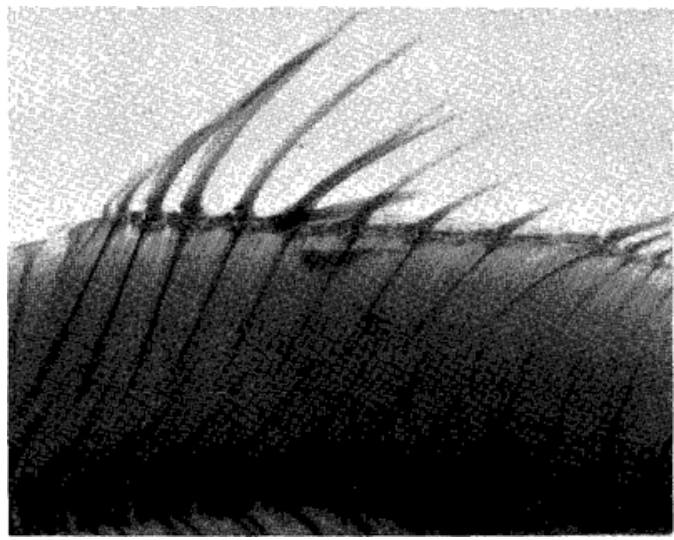

Fig. 2. Positive print of soft X-ray of the region of the first dorsal fin of this anomalous specimen. Note the absence of radials for the anomalous spines in the first dorsal fin.

I cannot prove from this anomalous specimen whether or not the anlage for spines $\mathrm{VI}^{\prime}$ to $\mathrm{IX}^{\prime}$ came from just the left side. While such a possibility is suggested, it is also possible that this aberrant fin anlage became oriented from bilaterally supplied mesenchyme before it was transferred along the dorsolateral intermuscular septum to the definitive location during larval development.

Lastly, the reduced spine $\mathrm{IX}^{\prime}$ is embedded on the outer surface of the regular scale located just dorsal to the 13th lateral line scale. This indicates that this spine may have developed from mesenchyme in very close proximity to the scale (also mesenchymal in orgin). This is an example of concresence.

In summary, my specimen presents evidence to support the theory that fin spines can develop alone without corresponding radials, radial muscles or neural spines of the axial skeleton. Also, a question is raised of the necessity for bilateral anlage sources for fin spines. Finally, an example of concresence of a fin spine with a body scale 1 s presented.

\section{ACKNOWLEDGMENTS}

Fishermen Ron Fithian and Nevitte Ford of Kent County, Maryland, discovered this specimen. George Clipper, Systematics Laboratory of the National Marine Fishery Service, National Museum of Natural History, Smithsonian Institution, Washington, D.C., Dr. Daniel Cohen, Director, provided the X-ray negative of the specimen. Mr. Arie DeKok of this UMCEES Lab assisted by translating several foreign language papers. I am especially appreciatıve to them and for the helpful interest and criticism generously given by my senior colleague, Dr. Ted S. Y. Koo.

\section{Literature Cited}

Burgess, G. H., and F. J. Schwartz. 1975. Anomalies encountered in freshwater and marine fishes from the eastern United States. The ASB Bull. 22(2):44.

Dawson, C. E. 1964. A Bibliography of Anomalies of Fishes. Gulf Research Reports 1(6):308-399. . 1966. A Bibliography of Anomalies of Fishes. Supplement 1. Gulf Research Reports 2(2):169-176. . 1971. A Bibliography of Anomalies of Fishes. Supplement 2. Gulf Research Reports 3(2):215-239. , and Elizabeth Heal. 1976. A Bibliography of Anomalies of Fishes. Supplement 3. Gulf Research Reports 5(2):35-41.

Goodrich, E. S. 1913. Studies on the Structure and Development of Vertebrates. Dover Publication, Inc., N.Y., N.Y. Vol. 1, Chapters 1-8, pp. 1xix + 485. Reprinted 1958.

Hildebrand, S. F., and W. C. Schroeder. 1928. Fishes of the Chesapeake Bay. Bull. U.S. Bur. of Fish. Vol. XLIII, Part 1, p. 244.

Douglas E. Ritchie, JR. ${ }^{2}$ Chesapeake Biological Laboratory

Center for Environmental and Estuarine Studies University of Maryland

Solomons, Maryland 20688

${ }^{2}$ Present address: Marine Extension, Extension Service Bldg., Prince Frederick, MD 20678.

\section{Variability of the Reverse-Flow Concentration Technique of Measuring Plankton Respiration}

ABSTRACT: Results from the reverse-flow concentration method used to determine community plankton respiration vary significantly because of met- abolic inactivation or losses of a portion of the concentrated sample during the filtering process. These losses seem to be nearly constant at concentrations greater 
than $150 \mathrm{X}$. The within sample coefficient of variation is $20-40 \%$ and is primarily a result of clumping and inadequate mixing before subsampling. A rapid processing of the samples is critical for best results.

\section{Introduction}

The measurement of plankton community metabolism is plagued with difficulties, not the least of which is the low level of plankton respiration. Pomeroy and Johannes $(1966,1968)$ introduced a reverse-flow conccntration method that overcomes the problem of relative insensitivity found in other methods. However, their method requires a correction factor because of processing procedures that converts the results back to the actual in situ respiration rates (Holm-Hansen et al. 1970).

There is some confusion in the literature as to what this correction factor should be. It can be determined by measuring some "conservative" property of the original water sample. Hobbie et al. (1972) quotes a correction factor of 3 , and Hobbie and Pomeroy (1972) a factor of 5 from an earlier paper (Holm-Hansen et al. 1970), which makes no specific reference to either number. Hobbie and Pomeroy (1972) also mention a correction factor of 8 for Hobbie's spinning filter, which was supposed to be 10 to 20 times as efficient as the reverse-flow concentration procedure in retaining bacteria in the concentrate. When I used the reverseflow concentration method to examine community plankton respiration in a Georgia salt marsh estuary and on the adjacent continental shelf (Turner in press), it became necessary to further examine the inherent variabilities.

\section{Materials and Methods}

The community plankton respiration rates of approximately 650 samples were routinely processed using the methods outlined by Pomeroy and Johannes $(1966,1968)$. This consisted of gently concentrating freshly collected seawater samples by reverse filtration through a $0.8 \mu$ Millipore $\AA$ filter of approximately $1600 \mathrm{~cm}^{2}$ area. Usually, 19.5 liters were concentrated to 5 to $500 \mathrm{ml}$ within 1 to 2 hours of collection. Material adhering to the filter was gently collected by rinsing with filtered sample water. The concentrate was then transferred by pipette to a graduated cylinder, the volume measured, gently mixed with a swirling motion, and immediately placed in a respirometer. The respirometer was soaked in $90 \%$ ethanol and rinsed with filtered seawater prior to use.

Oxygen uptake was measured with Kanwisher-type electrodes (Kanwisher 1959) in $5 \mathrm{ml}$ respirometers that were equipped with a small, magnetically driven paddle. The electrodes were calibrated in a solution standardized by Winkler titration. Oxygen consumption of the electrodes was checked prior to use and the results were considered unacceptable $(<5 \%$ of all samples) if (1) the hourly blank slope was greater than $4 \%$ of the full scale per hour, or (2) the recorded oxygen consumption per hour of sample + electrode was less than twice the rate of the blank, or less than $5 \%$ of the full scale. All routine measurements were performed at the in situ water temperature.
The effects of changing the various procedures in collection, concentration, and processing were examined. Chlorophyll and pheopigments in the original and concentrated samples were analyzed with a Turner® fluorometer (Strickland and Parsons 1968). Particulate carbon was measured using Reeve Angel $984 \mathrm{~A}$ filters $($ and a carbon-hydrogen analyzer. The incorporation of carbon- 14 by phytoplankton in the concentrate was measured by using a fluorescent light water bath according to the methods outlined in Strickland and Parsons (1968). These samples were rediluted to the original concentration to avord the effects of concentration mentioned by Morris et al. (1971).

Samples from the tidal creeks of Romerly Marsh and in Wassaw Sound near the Skidaway Institute of Oceanography Laboratory at Savannah, Ga., were collected between 1000 and $1300 \mathrm{hr}$. The samples were concentrated and the respiration rate recordings initiated within 1 hour upon return to the laboratory. Other supplementary samples were collected aboard the R/V EASTWARD in the Georgia continental shelf waters.

\section{Results and Discussion}

Oxygen consumption was consistently observed to be linear over time down to $30 \%$ oxygen saturation. Samples treated with formalin and/or $\mathrm{HgCl}_{2}$ underwent no detectable chemical oxidation. Clumping within the concentrate was a source of variability, noticed also by Holm-Hansen et al. (1970). The within-sample coefficient of variation was usually 20 to $40 \%$ for replicates of three or more. Among sample variation was low, and delays in processing the samples usually resulted in a change in final respiration rate when compared to control samples (Table 1). Therefore, data should be considered acceptable only if processing is completed within 4 hours of collection. Not thoroughly mixing the concentrate just before taking a subsample is another large source of variability.

The effect of degree of concentration on retention of chlorophyll, pheopigments, and carbon in these experiments is shown in Fig. 1. For these materials, correction factors of $1.5,1.5$, and 2.0 , respectively, seemed necessary to convert back to the in situ concentration when concentrating samples $150 \mathrm{X}$ or more (the

TABLE 1. The effect of delaying the initiation of the concentration process on the measured community plankton respiration rate (mg at $0 \mathrm{~m}^{-3}$ day $\left.^{-1}\right)^{*}$.

\begin{tabular}{ccc}
\hline \multicolumn{2}{c}{ Sample collection at $0945 \mathrm{hr}$} & \\
\cline { 1 - 2 } $\begin{array}{c}\text { Start of Concen- } \\
\text { tration (hr) }\end{array}$ & $\begin{array}{c}\text { End of Concen- } \\
\text { tration (hr) }\end{array}$ & Respiration \\
\hline 1000 & 1100 & 10.2 \\
1005 & 1114 & 10.9 \\
1010 & 1130 & 10.4 \\
1200 & 1300 & 12.1 \\
1205 & 1420 & 15.8 \\
1350 & 1505 & 48.9 \\
1413 & 1520 & 4.6 \\
1455 & 1605 & 124.6 \\
\hline
\end{tabular}

* The initial volume of each sample was 305-324 tumes the final volume. 
curve was fit by eye). Below $150 \mathrm{X}$ concentration, the results were more variable. Respiration rate vs. concentration, and carbon-14 incorporation vs. concentration relationships also followed this same pattern (Figs. 2 and 3). The correction factor for the latter, however, was about 3.0. The losses of pigment and carbon represented minimum losses of material but did not include the losses due to inactivation of organisms as did the carbon-14 incorporation experiments. Therefore, a filter correction factor of 3 seems acceptable for these particular waters when concentrating $150 \mathrm{X}$, or more. When concentrating samples less than $150 \mathrm{X}$, a concurrent determination of metabolic activities (e.g., carbon-14 uptake or enzyme activity) in the concentrate and the original sample is necessary for
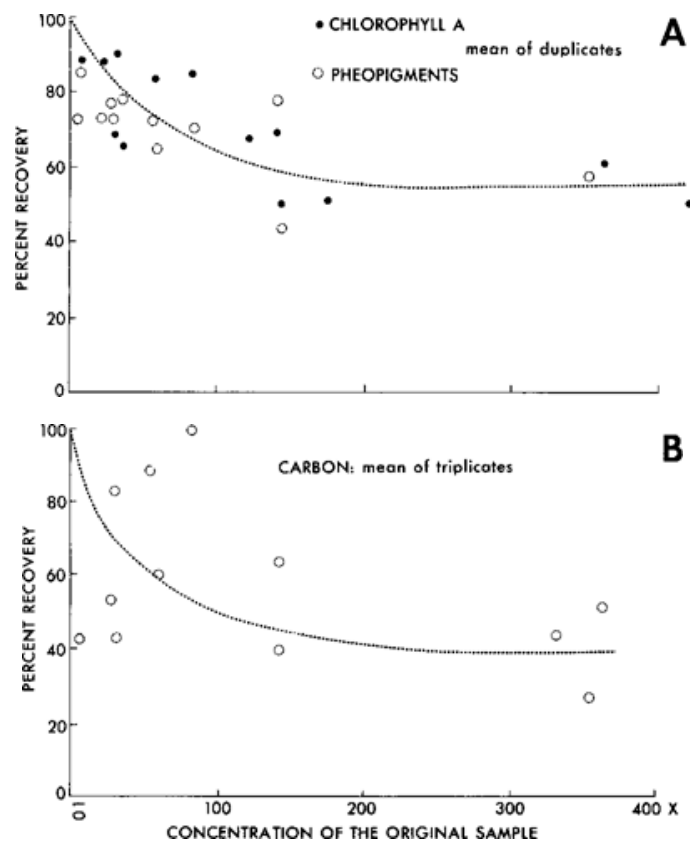

Fig. 1. The effect of concentrating the sample on the recovery of chlorophyll and pheopigments (A), and carbon (B).

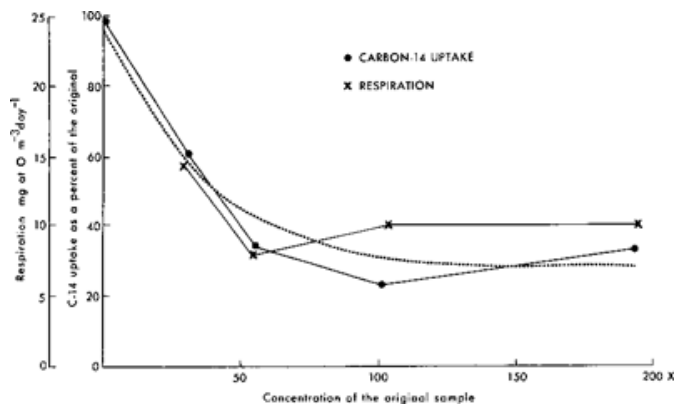

Fig. 2. An example of the effect of concentrating the original sample on the uptake of carbon-14 and of respiration by the concentrate.

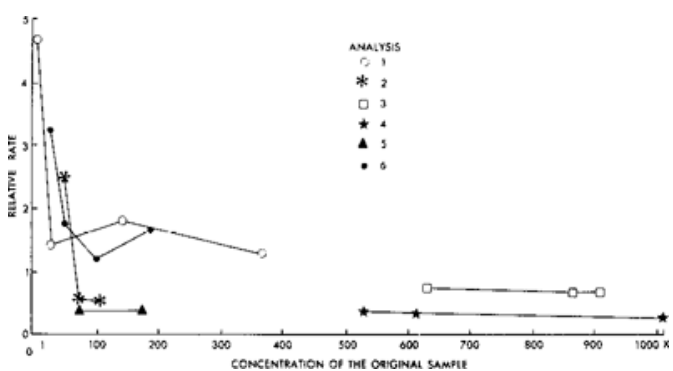

Fig. 3. The effects of the concentration process on the respiration rate of the sample. The absolute rates

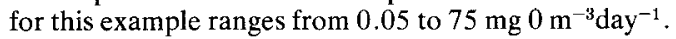

each sample in order to determine a filter correction factor.

These results clearly show the importance of considering the degree of concentration when interpreting results that we obtained with the reverse-flow concentration method. That other investigators have not considered the latter problem (with the exception of Pomeroy and Johannes 1966) explains much of the variability of their data. In fact, Griffiths et al. (1973) have criticized this method because of the variability in their own results. Their procedures were significantly different from those used in this study; they concentrated their samples $86 \mathrm{X}$ and $126 \mathrm{X}$, yet their results suggest that a filter correction factor of 3 was also appropriate. However, there is not yet sufficient evidence to apply any one correction factor for all waters. In summary then, while the variabilities in the method leave room for further improvement in technique, they can be minimized by observing the cautions pointed out here.

\section{ACKNOWLEDGMENTS}

This paper is a portion of a dissertation submitted to the Graduate Faculty of the University of Georgia, Athens. L. R. Pomeroy served as major advisor. The research was supported by a National Science Foundation Pre-Doctoral Fellowship from Duke University Cooperative Oceanographic Program, Grant \#GA27725 , and also by the Louisiana Sea Grant Program, part of the National Sea Grant Program maintained by the National Oceanic and Atmospheric Administration.

\section{Literature Cited}

Griffths, R. P., F. J. Hanus, and R. Y. Morita. 1973. Applicability of the reverse flow filter technique to marine microbial studies. Appl. Microbiol. 26(5):687-691.

Hobbie, J. E., O. Holm-Hansen, T. T. Packard, L. R. Pomeroy, R. W. Sheldon, J. P. Thomas, and W. J. Wiebe. 1972. A study of the distribution and activity of microorganisms in ocean water. Limnol. Oceanog. 17:544-555.

, AND L. R. Pomeroy. 1972. Experimental concentration of aquatic microorganisms. Verh. Internat. Verein. Limnol. 18:696-700. 
Holm-Hansen, O., T. T. Packard, and L. R. PomEROX. 1970. Efficiency of the reverse-flow filter technique for concentration of particulate matter. Limnol. Oceanog. 15:832-835.

Kanwisher, J. 1959. Polarographic oxygen electrode. Limnol. Oceanog. 4:210-217.

Morris, I.. C. M. YentsCh, AND C. S. Yentsch. 1971. Relationship between light carbon dioxide fixation and dark carbon dioxıde fixation by marine algae. Limnol. Oceanog. 16:854-859.

Pomeroy, L. R., and R. E. Johannes. 1966. Total plankton respiration. Deep-Sea Res. 13:971-973.

$\longrightarrow$, AND 1 . 1968 . Occurrence and respiration of ultraplankton in the upper 500 meters of the ocean. Deep-Sea Res. 15:381-391.

Strickland, J. D. H., AND T. R. Parsons. 1968. A practical handbook of sea water analysis. Fish. Res. Bd. Canada Bull. 167, 309 p.

TURner, R. E. (In press) Community plankton respiration in a salt-marsh estuary and the importance of macrophytic leachates. Limnol. Oceanogr.

\section{R. Eugene Turner}

Department of Martne Sciences

Louisiana State University

Baton Rouge, LA 70803

\section{Succession of Copepod Species in a Middle Atlantic Estuary}

\begin{abstract}
A study of the seasonal succession of dominant copepod species was conducted during the period May, 1972 to June, 1973 in the Navesink River estuary, a tributary of the New York Bight. The replacement of the copepod Acartia tonsa by Acartia clausi, a phenomenon well-documented in the middle Atlantic estuaries for the late winter and early spring seasons, was not observed during this study, indicating that this succession may not take place in the Navesink. Instead, the more brackish-water calanoids, Pseudodiaptomus coronatus and Eurytemora affinis replaced $A$. tonsa, increasing in numbers markedly as the $\boldsymbol{A}$. tonsa population declined. Although $A$. clausi is known to occur in temperatures and salinities comparable to those of the Navesink, this study supports the results of Yamazi (1966) that the occurrence of $A$. clausi in the Navesink is a rarity.
\end{abstract}

\section{Introduction}

The succession of dominant copepod species was studied during the period from May, 1972 through June, 1973 as part of a larger investigation of the effects of domestic sewage abatement in the Navesink River estuary. The Navesink River estuary is contiguous with the commercially productive New York Bight (Fig. 1). The river extends nine kilometers from its two major freshwater sources, Swimming River and Shadow Lake, to its mouth. Narrowed at the mouth by marshes, the Navesink joins the Shrewsbury River, discharging into Sandy Hook Bay, an embayment located within the New York Bight.

Yamazi (1966) characterized the dominant zooplankton communities and adjacent waters of the Shrewsbury River and Sandy Hook Bay during his May-June survey of 1962 . The zooplankton of the contiguous areas of Sandy Hook and Raritan bays has been studied by Sage and Herman (1972) and Jeffries $(1959,1962,1964)$, respectively, with particular emphasis on the succession of Acartia copepod species. In Sandy Hook and Raritan bays, seasonal succession is dominated by the presence of Acartia tonsa and its replacement by Acartia clausi in the spring, particularly during June. However. Yamazi (1966) reported the presence of $A$. clausi as rare in the Navesink during his May-June survey. Excepting Yamazi, no data are available on the copepod populations of the Navesink.

I am indcbtcd to John B. Pearce, Officer-in-Charge, Sandy Hook Laboratory, Lion Gardiner, Rutgers University, and Newell Eisele. Sandy Hook Laboratory, for their assistance and contributions to the investigation, and John L. Dawson, Allan Hancock Foundation, University of Southern California, for verification of copepod identifications.

\section{Materials and Methods}

Sampling stations (Fig. 1) were visited weekly from May through August 1972. Beginning in September, until termination of sampling in June, 1973, sampling was conducted at two to three week intervals, excluding January, when ice prohıbited sampling. All cruises were made at flood tide.

Conductivity, salinity and temperature were measured at surface and bottom depths at each station with a Beckman model RS-5 electrodeless, induction salinometer. A quantitative zooplankton sample was taken at each station with a half-meter No. 8 mesh $(0.203 \mathrm{~mm})$ net equipped with a T.S.K. model flowmeter. Each tow consisted of a 1-minute surface and a 4-minute oblique haul. Zooplankton samples were preserved in $10 \%$ buffered seawater-formalin. When ctenophores were abundant, the sample was strained through a $4 \mathrm{~mm}$ sieve to remove them.

Laboratory analysis of zooplankton, according to the method of Frolander (1968), consisted of diluting the sample to a known volume, extracting the subsample with a Stemple prpette, and counting and identifying the organisms. Subsamples were drawn from each sample until a minimum of 400 copepods were counted.

\section{Results \\ TEMPERATURE}

The range of water temperatures recorded varied from $31.9^{\circ} \mathrm{C}$ at station 1 on 19 July to $3.0^{\circ} \mathrm{C}$ at stations 1 and 3 on 7 February. In January, surface water 